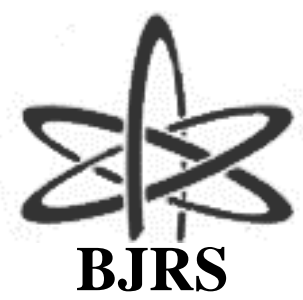

\author{
BRAZILIAN JOURNAL \\ $\mathrm{OF}$ \\ RADIATION SCIENCES \\ 07-2A (2019) 01-14
}

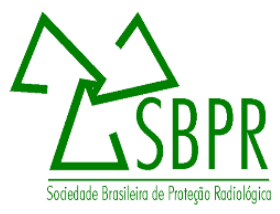

\title{
Remediation of Caldas site by monitored natural
}

\author{
recovery \\ R. D. A. Chaves; P. C. H. Rodrigues; A. C. Q. Ladeira \\ Centro de Desenvolvimento da Tecnologia Nuclear - CDTN/Comissão Nacional de Energia Nuclear - CNEN, 31270- \\ 901 Belo Horizonte, $M G$, Brasil \\ $r d a @ c d t n . b r$ \\ pchr@cdtn.br \\ acql@cdtn.br
}

\begin{abstract}
Acid mine drainage (AMD) is one of the main environmental issue caused by oxidation of pyrite $\left(\mathrm{FeS}_{2}\right)$ when exposed to atmospheric conditions during mining. In Brazil, one of the places where AMD occurs is an old uranium mine in Minas Gerais State. The acid waters contain radionuclides and other metals that are precipitated with the addition of lime. Due to the inefficiency of the water treatment plant, part of the precipitate containing the metals overflows from the settling tanks and reach the water reservoir of Indústrias Nucleares do Brasil - INB. The multiplicity of interactions that can occur between the extremely fine particles of the precipitate and the sediments of the reservoir requires a broader approach in order to understand the fixation and/or transport of the metals. In this work the natural recovery approach is reviewed and a chemical and radiochemical characterization of the sediments are presented. Uranium and thorium were determined by spectrophotometry, ${ }^{226} \mathrm{Ra},{ }^{228} \mathrm{Ra}$ and ${ }^{210} \mathrm{~Pb}$ by gamma spectrometry and $\mathrm{Zn}$ and Mn by ICP-OES. A panorama of the contamination is shown in different maps by using ArcGis program. Twenty-six sediment samples were collected in the reservoir and a bathymetry survey by sonar was performed to determine the thickness of the sediment layer. Most of the samples have presented activity concentrations of uranium and thorium higher than the background values. Further investigation will assess the potential mobility and bioavailability of contaminants and the role of bacterial sulfate reduction in the immobilization of these contaminants.
\end{abstract}

Keywords: sediments, acid mine drainage, uranium, zinc. 


\section{INTRODUCTION}

Mining is a strategic activity in the world economy and has its importance recognized for the development of Brazil, which is one of the main exporters of several minerals. However, if appropriate environmental practices are not adopted, mining activities could be sources of inorganic contamination [1]. One environmental problem of great concern is acid mine drainage (AMD). It is caused mainly by oxidation of pyrite $\left(\mathrm{FeS}_{2}\right)$ when exposed to air and water during the mining process causing the generation of acidity $\left(\mathrm{H}^{+}\right)$. As an aggravating factor, this process can be catalyzed by bacteria activity that greatly accelerate acid producing reactions.

The acid effluent is characterized by low $\mathrm{pH}$ and high content of sulfate and dissolved metals [1, $2,3,4]$. Due to its high capacity to leach the elements present in the ore it can contaminate surface water and groundwater. AMD sources include waste rock piles, ore stockpiles, tailings storage facilities and tailings dams, open cuts, underground mines and heap and dump leach piles. This problem is not exclusive to mining activities and can occur in any operation that results in a large movement of soil and rocks containing $\mathrm{FeS}_{2}$. The sulfide minerals responsible for AMD can be found in coal or nickel, lead, zinc, copper, uranium, gold and silver ores. The AMD occurrence can be predicted by determining the minerals that constitute the ore and their potential risks associated to acid generation. The focus should be on prevention or minimization rather than on treatment [3].

In Brazil, AMD occurs in a uranium mine in Caldas Municipality, Minas Gerais State, which is under decommissioning. Before being discharged to the environment, the levels of metals and sulfate present in the AMD are reduced by raising the $\mathrm{pH}$ with lime. However, part of the precipitate containing $\mathrm{Zn}, \mathrm{Mn}, \mathrm{Pb}, \mathrm{U}$ and $\mathrm{Ra}$, reaches a water reservoir that belongs to Indústrias Nucleares do Brasil - INB, leading to a concern about the sediment contamination and the migration of the metals to the environment.

The reservoir under study is located in Antas creek, downstream the water treatment plant, with a drainage area of approximately $50 \mathrm{~km}^{2}, 3.5 \mathrm{~km}$ length and $250 \mathrm{~m}$ of average width. During mining activities, it was used to supply water to the ore treatment plant from INB. Currently, the treated effluent flows to the reservoir and previous study shows that the sediments are contaminated with metals, including uranium, whose contents are above the background levels [4]. The study 
investigated only 4 points and not all the radionuclides were investigated. So, a deeper investigation is necessary as the contaminants can be toxics to the environment, due to the deleterious or adverse biological effect caused by chemical, physical or biological agents. According to the Environmental Protection Agency (EPA) [5], contamination is the introduction of harmful or hazardous matter into the environment, where it should not be or it is at concentrations above background.

The recognition of the environmental risks of AMD has led to the development of several techniques to minimize their impact on the ecosystem. Although conventional neutralization systems through the addition of alkaline reagents are the most commonly used, systems containing sulfate-reducing bacteria are also employed for $\operatorname{AMD}$ treatment [1, 2, 3]. Effective sediments remediation actions must consider the relative importance of these two processes, sulfide oxidation and bacterial sulfate reduction [6].

This study investigated the sediments of one water reservoir, highly affected by uranium mining activities, in order to determine the capacity of the system to undergo natural attenuation. For that, a chemical and radiochemical characterization of the sediments as a preliminary assessment of the main radionuclides was carried out. The thickness of the sediments was also determined by bathymetry survey and data obtained were treated by using ArcGIS program.

\subsection{Monitored Natural Recovery in Site Remediation}

EPA published in 2005 a document that provides technical and policy guidance for managing contaminated sediment sites [7]. According to this document, monitored natural recovery (MNR) is a choice for the remediation of contaminated sediment that generally uses continuous naturally occurring processes to contain, destroy, or decrease the bioavailability or toxicity of contaminants in sediments. Some of the natural processes result in the lowering of risks, however, some of them may increase or change risks to other places or receptors. MNR may use processes that include physical, biological, and chemical mechanisms acting together to reduce the risk posed by the contaminants. Depending on the contaminants and the environment, the reduction of the risks may occur in different ways, e.g., the contaminant may be changed to a less toxic form through mechanisms such as biodegradation or abiotic transformation; the mobility and bioavailability of the contaminants may be reduced through sorption or other processes that bind contaminants to the 
sediment matrix [7]. These cited mechanisms are the most important ones for the present investigation.

In most cases, the main advantages of MNR are its relatively low implementation cost and its non-invasive nature. While costs of characterization and modeling can be high, in MNR, they are more associated with just monitoring. Other positive facts may include no needs for infrastructure, therefore, becoming much less disruptive for communities than dredging or in-situ capping [7].

MNR limitations can include the permanence of the contaminants in place and its slow reduction of risks in comparison to active remediation processes. Moreover, there is risk of contaminants re-exposure. Uncertainties usually related to MNR include the incapability of predicting future sedimentation rates in dynamic environments and of predicting contaminant flux rates through stable sediments [7].

The success of MNR as a risk decreasing mechanism mostly depends on the understanding of the dynamics of the contaminated environment and the destination and mobility of the contaminant in that location. Chemical processes in sediments are very important for metals. The chemical state of metals in the sediments is ruled by many environmental variables that influences their mobility, toxicity and bioavailability. Much of the current knowledge of the role of chemical processes in risk control is focused on the important geochemical changes that come from changes in the redox potential and that may have influence in the bioavailability of metal and metal organic compounds. The formation of biogenic metal sulfides, under reducing conditions, can frequently and effectively control the risk of metal contaminants if the appropriate environmental conditions are sustained. This process produces alkalinity and causes the refixation of sulphur as sulphide minerals in the sediment matrix. Besides that, many chemical processes in sedimentary environments are affected by the biological community as well $[7,8]$.

For the assessment of potential bioavailability of metals in river sediments, a traditional method is the AVS/SEM which determines the acid volatile sulfide (AVS) and the metals that are dissolved during the acidification step (Simultaneously Extracted Metals-SEMs) [8, 9]. Sulfate from the AMD can be reduced to sulfide due to bacterial action. These sulfides formed by microbial reduction of $\mathrm{SO}_{4}{ }^{2-}$ are consisted mainly of free sulfides, $\mathrm{FeS}$, and $\mathrm{Fe}_{3} \mathrm{~S}_{4}$, as well as relatively low solubility metal sulfides such as copper, nickel, zinc, cadmium, and lead [10, 11, 12]. 
The literature reports three criteria to express the relationship between AVS and metal toxicity: (i) the difference between SEM and AVS ( SEM - AVS), (ii) the ratio of SEM to AVS ( $\sum \mathrm{SEM} / \mathrm{AVS}$ ), and (iii) the SEM to AVS difference normalized by the fraction of total organic carbon (TOC) in a sediment ((SEM - AVS)/TOC). Normalization by TOC is justified by the fact that organic matter is intrinsically related to the bioavailability of the metals $[10,11,12]$, once the organic matter is an important source of extra binding capacity, forming less toxic complexes.

Other studies have shown that the toxicity to benthic organisms does not occur when the concentration of AVS is greater than the sum of simultaneously extracted metals SEM from the sediment. This assumption is based upon the low solubility of the metal sulfides which are removed from the soluble fraction by precipitation. However, it should be considered that the sequence of precipitation depends on the solubility of the solid sulfide $[10,11]$. An understanding of the distribution of dissolved species in AVS is important to comprehend the biogeochemistry of sulfidic natural systems. In the next step of this study, AVS analyzes will be carried out.

The biogenic sulfides can also be studied trough isotopic analyses. In nature, sulfur has four stable isotopes $\left({ }^{32} \mathrm{~S},{ }^{33} \mathrm{~S},{ }^{34} \mathrm{~S}\right.$ and $\left.{ }^{36} \mathrm{~S}\right)$ with relative abundances of $95 \%, 0.75 \%, 4.2 \%$ and $0.017 \%$, respectively. In general, the biogenic sulfides are depleted in ${ }^{34} \mathrm{~S}$. It means that the sulfate with lighter sulfur isotopes are preferably metabolized because of their weaker chemical binding. The isotopic ratio $\left(\delta^{34} \mathrm{~S}\right)$ used in concert with physical and chemical parameters can provide useful information about the occurrence and extension of sulfur redox processes, one of the mechanisms responsible by natural recovery $[6,13]$.

\section{MATERIALS AND METHODS}

Twenty-six sediment samples were collected in different points including the point of discharge of the treated water and two background points upstream of the water reservoir. For the characterization, the samples were dried, ground, sieved, and then digested in acidic media in microwaves. Uranium and Thorium were determined by spectrophotometry, Ra-226, Ra-228 and $\mathrm{Pb}-210$ by gamma spectrometry and $\mathrm{Zn}$ and Mn by ICP-OES. 
A bathymetry survey by sonar (GARMIN echoMAP TM 50dV) in a zig-zag route with a mean distance between the vertices of 100 and 200 meters was performed to determine the thickness of the sediment layer and the data were processed through the Garmim HomePort $@$ software. For regions with water depth less than $50 \mathrm{~cm}$, it was necessary to use a ruler to determine the sediment depth. All the data of characterization and bathymetry were processed using the ArcGIS program.

\section{RESULTS AND DISCUSSION}

The data of the volumetric survey carried out in the water reservoir are illustrated in the Fig. 1. The data were processed through the ArcGis software. According to the data, the total volume of the reservoir was approximately $3,750,696 \mathrm{~m}^{3}$ and the sediment volume was approximately 409,848 $\mathrm{m}^{3}$.

Figure 1: The Bathymetry Survey Route at the water Reservoir

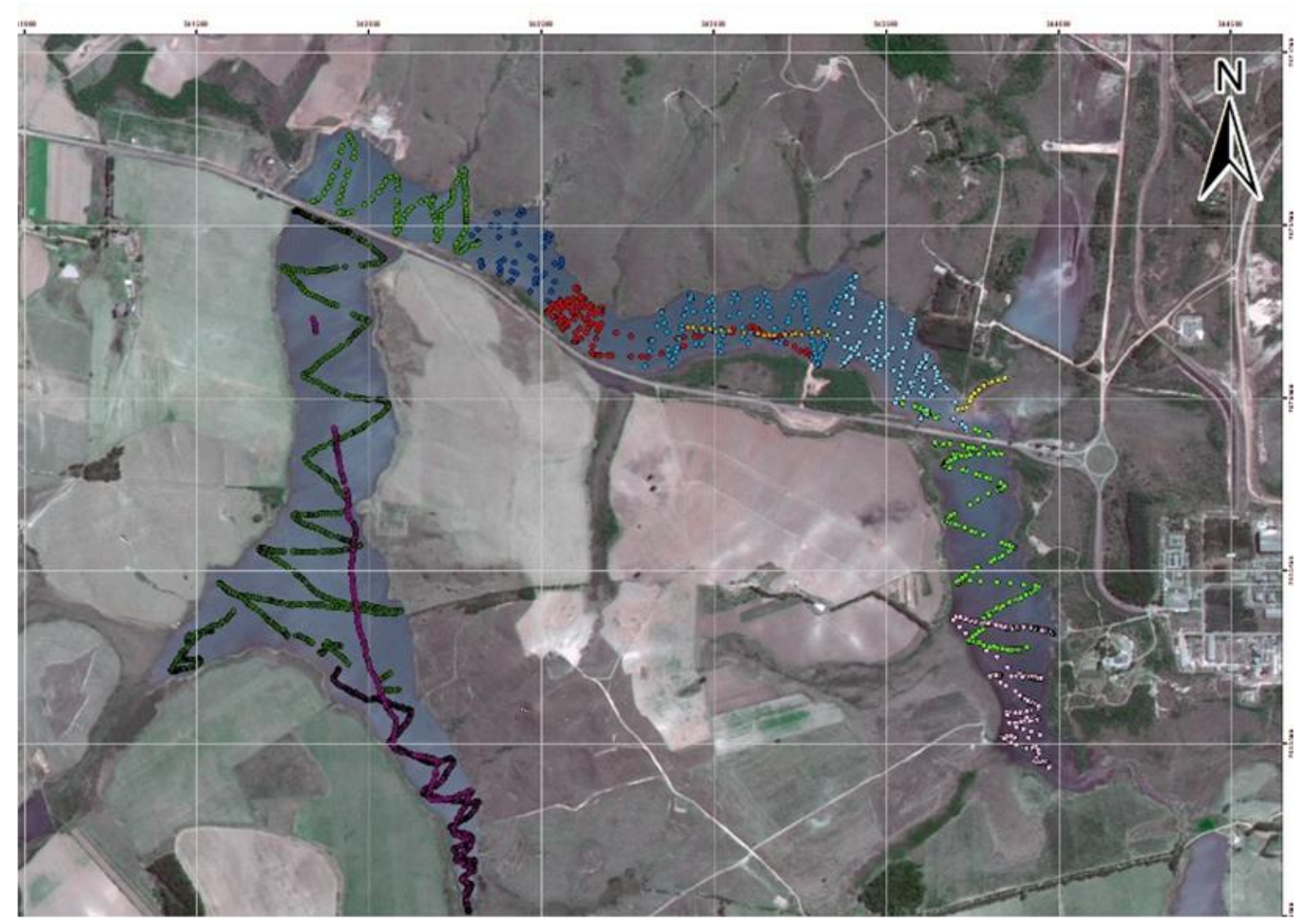


Source: Unidade de Tratamento de Minérios - INB

Figure 2 presents the data of the thickness of the sediment layer by interpolation using the settings: IDW (Inverse Distance Weighting) interpolation method and the color classification with 10 classes and geometric intervals. The location of the point, where the treated water is discharged to the reservoir, is highlighted in black in Figure 2. It is observed that the sediment layer in this point is extremely thick, ranging from 1.11 to $2.83 \mathrm{~m}$, similar to the orange region in the left side that is justified by the topography of the region.

Figure 2: The Sediment Layer Thickness in the water Reservoir

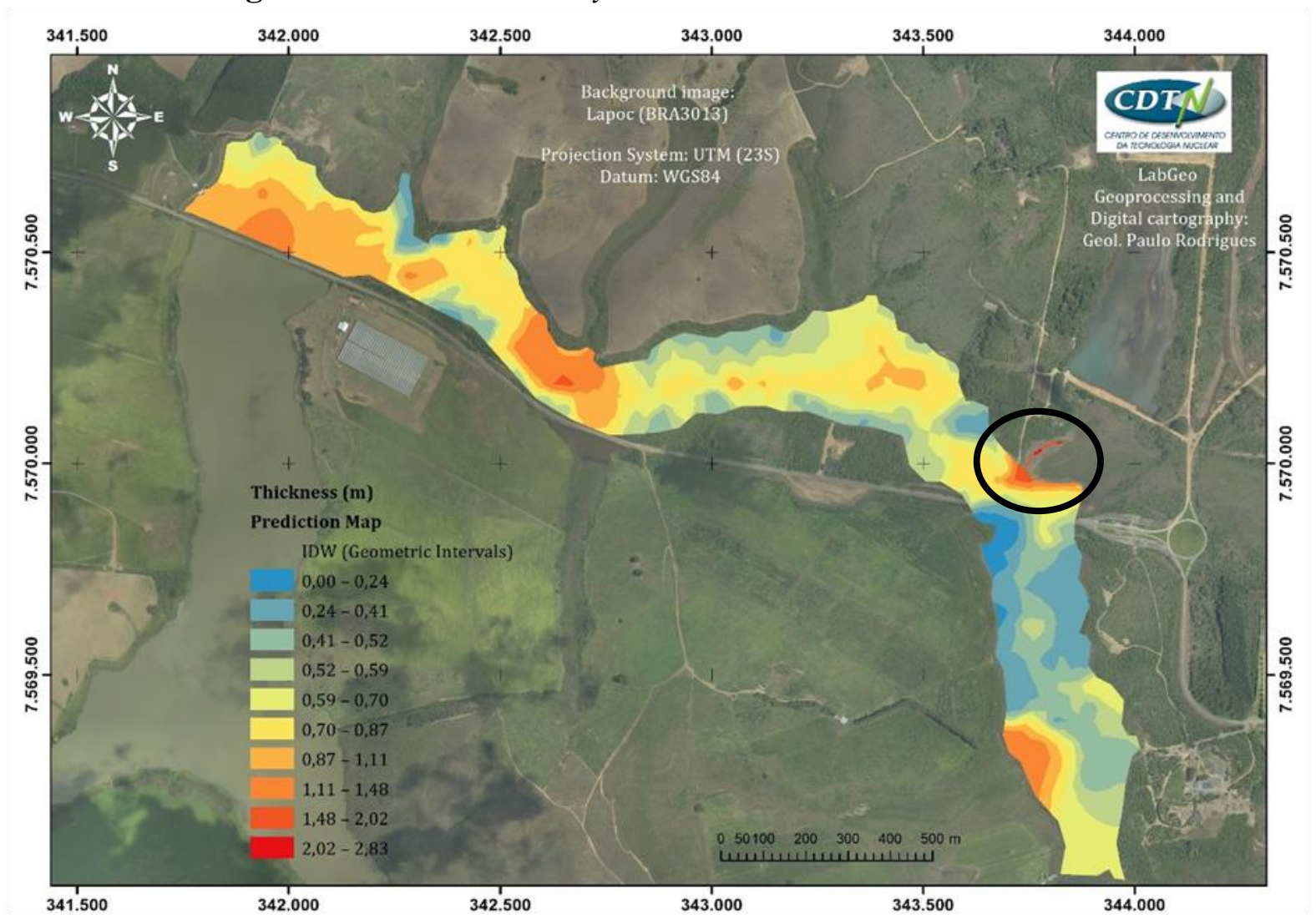

Source: LabGeo Geoprocessing and Digital cartography: Geol. Paulo Rodrigues - CDTN 
According to the sediment volume and the CONAMA Resolution No. 454/2012 [14], twenty six sampling points were selected in the reservoir. The characterization of all the samples are showed on Table 1.

Table 1: Chemical and Radiochemical Characterization of the Sediments of the water Reservoir.

\begin{tabular}{|c|c|c|c|c|c|c|c|}
\hline Elements & U-nat & Ra-226 & Ra-228 & Pb-210 & Th & MnO & $\mathrm{ZnO}$ \\
\hline Samples & $\mathrm{Bq} \mathrm{kg}^{-1}$ & $\mathrm{~Bq} \mathrm{~kg}^{-1}$ & $\mathrm{~Bq} \mathrm{~kg}^{-1}$ & $\mathrm{~Bq} \mathrm{~kg}^{-1}$ & $\mathrm{~Bq} \mathrm{~kg}^{-1}$ & $\%$ & $\%$ \\
\hline Bkg 013 & 230 & 150 & $<4100$ & 210 & 11 & 0.82 & 0.06 \\
\hline Bkg 084 & 160 & 220 & $<4700$ & 280 & 11 & 0.45 & 0.08 \\
\hline 0191 & 6700 & 880 & 490 & 240 & 490 & 0.53 & 0.12 \\
\hline 0221 & 5700 & 300 & 370 & 160 & 410 & 0.48 & 0.12 \\
\hline 0231 & 7700 & - & 530 & 430 & 890 & 0.08 & 0.04 \\
\hline 0751 & 7300 & - & 460 & 170 & 520 & 0.11 & 0.06 \\
\hline 0761 & 8100 & - & 460 & 170 & 540 & 0.07 & 0.03 \\
\hline 0971 & 8400 & 400 & 320 & 140 & 350 & 0.64 & 0.36 \\
\hline 0981 & 5700 & 150 & 250 & 78 & 460 & 0.13 & 0.05 \\
\hline 0991 & 6900 & - & 290 & 51 & 380 & 0.08 & 0.22 \\
\hline 1001 & 3900 & 500 & 220 & 280 & 170 & 0.07 & 0.13 \\
\hline 1011 & 3700 & 480 & 600 & 240 & 920 & 0.16 & 0.14 \\
\hline 1021 & 11000 & - & 430 & - & 510 & 0.86 & 0.19 \\
\hline 1031 & 12000 & 340 & 450 & 140 & 500 & 0.06 & 0.25 \\
\hline 1061 & 8500 & 160 & 270 & $<23$ & 400 & 0.29 & 0.16 \\
\hline 1071 & 12000 & 440 & 430 & 940 & 86 & 0.07 & 0.18 \\
\hline 1081 & 5000 & 380 & 540 & 340 & 590 & 0.18 & 0.17 \\
\hline 1091 & 8100 & 200 & 290 & 310 & 500 & 1.13 & 0.10 \\
\hline 1101 & 11000 & 570 & 520 & 460 & 310 & 0.26 & 0.09 \\
\hline 1111 & 20000 & 120 & 250 & $<64$ & 370 & 0.06 & 0.19 \\
\hline 1121 & 29000 & 130 & 360 & 390 & 550 & 0.10 & 0.17 \\
\hline
\end{tabular}




\begin{tabular}{cccccccc} 
AM1 & 340 & - & 17 & $<51$ & $<270$ & 0.09 & 0.15 \\
AM2 & 470 & - & $<37$ & $<48$ & $<300$ & 0.33 & 0.15 \\
AM3 & 200 & - & $<37$ & $<52$ & $<140$ & 0.14 & 0.20 \\
AM4 & 310 & 32 & $<14$ & $<49$ & $<250$ & 0.17 & 0.20 \\
AM5 & $<220$ & $<39$ & $<29$ & $<42$ & $<220$ & 0.45 & 0.32 \\
AM6 & 20000 & 280 & 340 & 71 & 520 & 0.70 & 0.62 \\
AM7 & 160 & - & $<26$ & $<30$ & $<96$ & 0.19 & 0.11 \\
\hline
\end{tabular}

$\mathrm{Bkg}=$ background

The two background points, Bkg 013 and Bkg 084, located upstream the reservoir, presented a uranium activity concentration of 230 and $160 \mathrm{~Bq} \mathrm{~kg}^{-1}$ and thorium activity concentration of $11 \mathrm{~Bq}$ $\mathrm{kg}^{-1}$ in both. The chemical and radiochemical characterization in the sediment samples evidenced a uranium activity concentration ranging from 160 to $29000 \mathrm{~Bq} \mathrm{~kg}^{-1}$ and a thorium activity concentration ranging from 86 to $920 \mathrm{~Bq} \mathrm{~kg}^{-1}$. All samples presented uranium and thorium activity concentrations higher than the background values, except the U in samples AM3, AM5 and AM7.

Figures 3 and 4 present the activity concentrations of uranium and thorium in the samples, respectively, and its location in the water reservoir. It can be observed that the radionuclides dispersion occurs according to the direction of the water flow in the reservoir. It is important to evaluate in the natural series of $\mathrm{U}$ and $\mathrm{Th}$, the radionuclides ${ }^{226} \mathrm{Ra},{ }^{228} \mathrm{Ra}$ and ${ }^{210} \mathrm{~Pb}$, the ones of most concern from the radiological point of view [15]. It can be seen that sample 0191 presents the highest ${ }^{226} \mathrm{Ra}$ activity concentration (Table 1 ). This point is located close to the spillway where the waters of the reservoir reach Antas Creek (Ribeirão das Antas), which may be explained by ${ }^{226} \mathrm{Ra}$ high environmental mobility.

The contents of $\mathrm{Mn}$ and $\mathrm{Zn}$ range from 0.06 to $1.13 \%$ and 0.03 to $0.62 \%$, respectively. The two background points presented a Mn concentration of 0.45 and $0.82 \%$ and $\mathrm{Zn}$ content of 0.06 and $0.08 \%$. 
Figure 3: Map of the U-nat activity concentration $\left(B \mathrm{~kg}^{-1}\right)$ in the water Reservoir

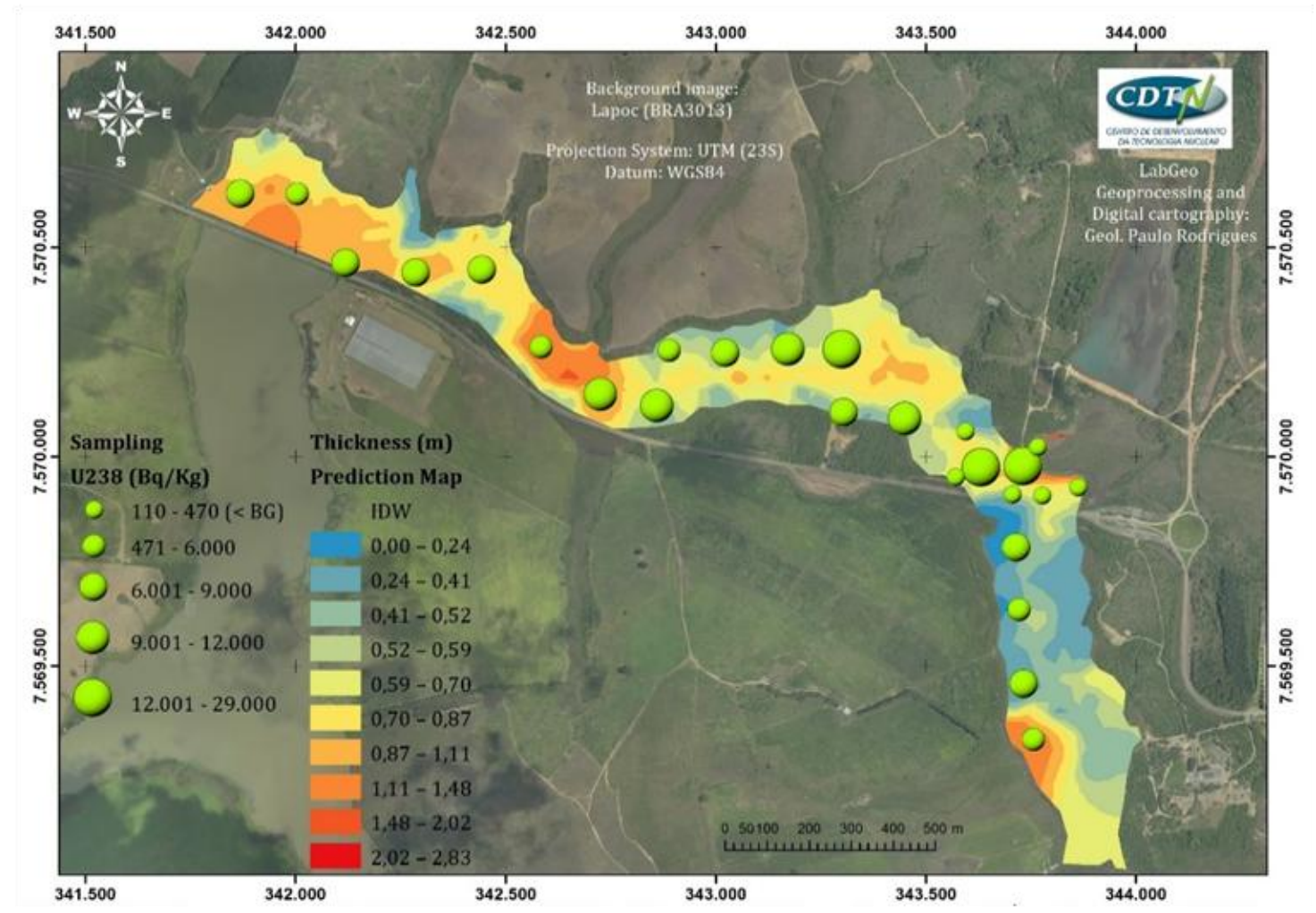

Source: LabGeo Geoprocessing and Digital cartography: Geol. Paulo Rodrigues - CDTN 


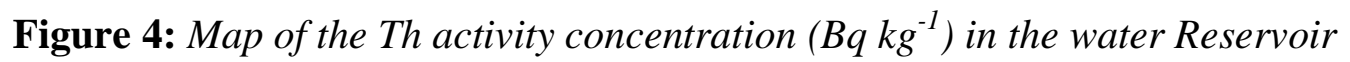

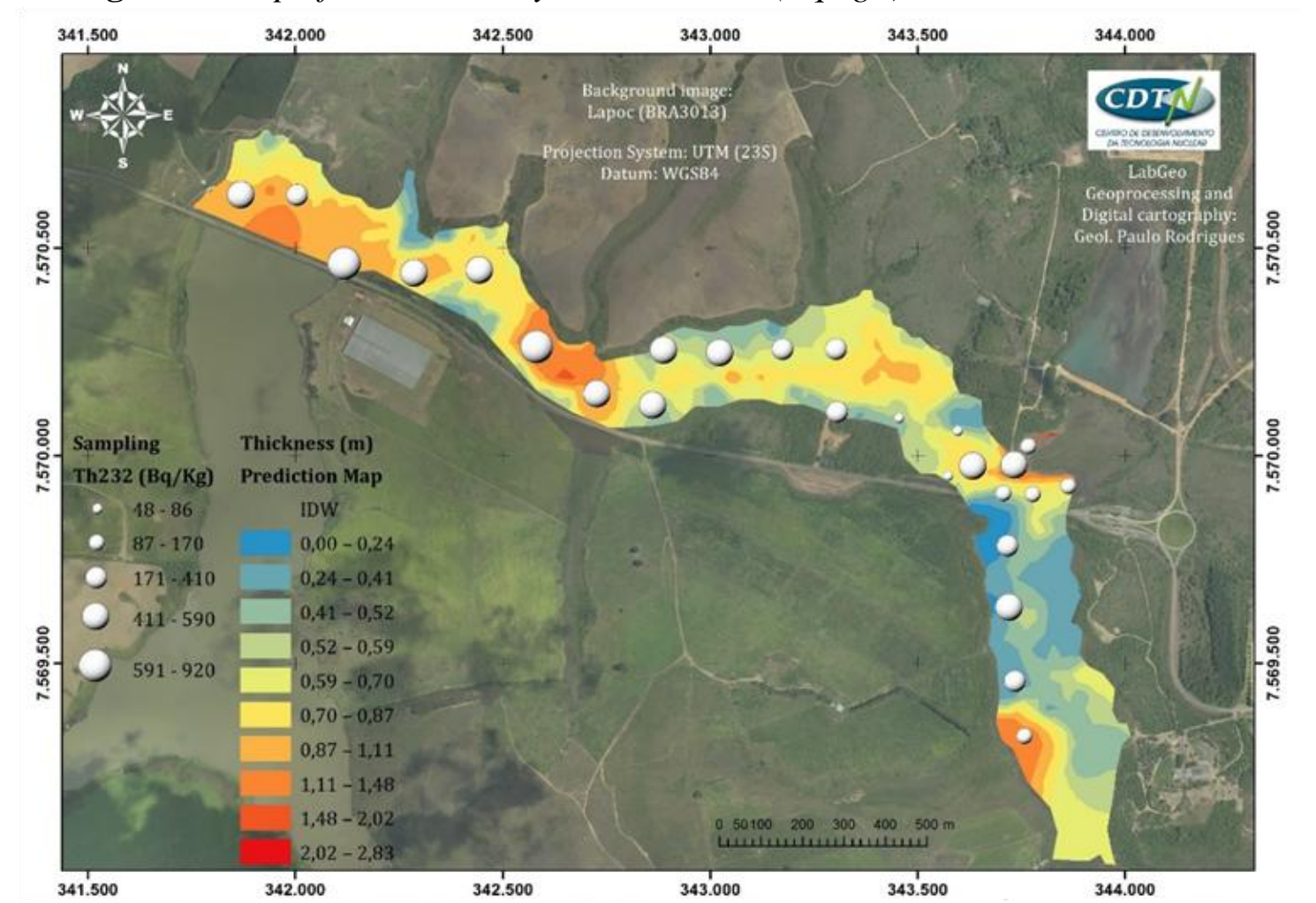

Source: LabGeo Geoprocessing and Digital cartography: Geol. Paulo Rodrigues - CDTN

\section{CONCLUSION}

The chemical and radiochemical characterization indicated the enrichment of radionuclides and other metals in the sediment samples if compared to the background of the region. However, the evaluation based only on the total concentration of metals is very limited, making it necessary to deepen the studies of mobility and availability of the metal species to the environment. Once the main contaminants were determined, their mobility and migration to the environment as well as the capacity of the system to undergo natural recovery will be assessed.

In some areas, natural recovery may appear to be the most appropriate remedy, mainly for its low cost and for not requiring any type of construction. This option should be considered in the water reservoir, taking into account the key role of sulfide in controlling bioavailability of metals in anoxic sediments as a precipitant agent of toxic metals. In order to assess the potential mobility and 
bioavailability of the contaminants and to study the role of bacterial sulfate reduction in their immobilization, it is proposed to use the AVS/SEM method along with other speciation tools such as ${ }^{32} \mathrm{~S}$ and ${ }^{34} \mathrm{~S}$ sulfur isotopic determination.

Other actions may be taken if the rate of sedimentation or the natural recovery are insufficient to reduce contamination within an acceptable period. If this is the case, project managers may consider accelerating the natural recovery process by some engineering mean [7].

\section{ACKNOWLEDGMENT}

Acknowledgements to CDTN, CNPq, Fapemig and INCT-Acqua for the financial support and to INB for collaboration.

\section{REFERENCES}

1. JAMBOR, J. L.; BLOWES, D. W.; RITCHIE, A. I. M., Environmental Aspects of Mine Wastes - Chapters 9 and 10, v. 31. Vancouver: Mineralogical Association of Canada, 2003. p. 181-226.

2. CAMPANER, V. P.; SILVA, W. L. Processos físico-químicos em drenagem ácida de mina em mineração de carvão no sul do Brasil. Química Nova, v. 32 (1), p. 146-152, 2009.

3. Mello, J. W. V.; DUARTE, H. A.; LADEIRA, A. C. Q. Origem e Controle do Fenômeno Drenagem Ácida de Mina. Cadernos Temáticos de Química Nova na Escola - QNESC, v. 8, p. 24-29, 2014.

4. SOUZA, L. R.; KNOLlER, K.; LADEIRA, A. C. Q., Sulfur isotope fractionation and sequential extraction to assess metal contamination on lake and river sediments. J Soils Sediments, v. 16 (7), p. 1986-1994, 2016.

5. EPA - United States Environmental Protection Agency. Superfund for Students and Teachers Glossary. Available at: <https://ofmpub.epa.gov/sor_internet/registry/termreg/search 
andretrieve/termsandacronyms/search.do> Last accessed: 10 Nov. 2018.

6. KNOLLER, K.; FAUVILLE, A.; MAYER, B.; STRAUCH, G.; FRIESE, K.; VEIZER, J. Sulfur cycling in an acid mining lake and its vicinity in Lusatia, Germany. Chemical Geology, v. 204, p. $303-323,2004$.

7. US EPA - United States Environmental Protection Agency. Contaminated Sediment Remediation: Guidance for Hazardous Waste Sites - EPA-540-R-05-012, Washington: DC, 2005. 236p.

8. KNOLLER, K.; JESCHKE, C.; SIMON, A.; GAST, M.; HOTH, N. Stable isotope fractionation related to technically enhanced bacterial sulphate degradation in lignite mining sediments. Isotopes in Environmental and Health Studies, v. 48 (1), p.76 - 88, 2012.

9. US EPA - United States Environmental Protection Agency. Draft Analytical Method for Determination of Acid Volatile Sulfide and Selected Simultaneously Extractable Metals in Sediment, EPA 821-R-91-100, Washington: DC, 1991. 22p.

10. DI TORO, D.M.; MAHONY, J.D.; HANSEN, D. J.; SCOTT, K. J.; CARLSON, A.R.; ANKLEY, G. T. Acid volatile sulfide predicts the acute toxicity of cadmium and nickel in sediments. Environmental Science and Technology, v. 26(1), p. 96-101, 1992.

11. US EPA - United States Environmental Protection Agency. Procedures for the Derivation of Equilibrium Partitioning Sediment Benchmarks (ESBs) for the Protection of Benthic Organisms: Metal Mixtures (Cadmium, Copper, Lead, Nickel, Silver and Zinc) - EPA 600-R-02-011, Washington: DC, 2005. 175p.

12. SOUZA, L. R.; KNOLLER, K.; LADEIRA, A. C. Q. Investigation into River Sediments Toxicity as a Result of Inappropriate Waste Disposal. Journal of Waste Management, v. 2013, 7 pages, 2013.

13. KROUSE, H. R.; GRINENKO V. A. Stable Isotopes: natural and Anthropogenic Sulphur in the Environment - THODE, H. G. Chapter 1. Sulphur Isotopes in nature and the Environment: An Overview. New York: John Wiley \& Sons, 1991. p. 1-26. 
14. MMA - Ministério do Meio Ambiente. CONAMA Resolução $\mathbf{N}^{\circ}$ 454, de 01 de novembro de 2012. Available at: <http://www.mma.gov.br/port/conama/legiabre.cfm?codlegi=693> Last accessed: 05 Jun. 2017.

15. TAUHATA, L.; VIANNA, M. E. C. M.; OLIVEIRA, A. E.; et al. The Brazilian National Intercomparison Program (PNI/IRD/CNEN): evaluation of 15 years of data. Journal of Environmental Radioactivity, v. 86, p. 384-390, 2006. 